\title{
Early Marriage, Marital Relations and Intimate Partner Violence in Ethiopia
}

\section{By Annabel Erulkar}

Annabel Erulkar is country director and senior associate, Population Council, Addis Ababa, Ethiopia.
CONTEXT: A considerable proportion of women worldwide are married during childhood. Although many studies have examined early marriage (before age 18), few have compared outcomes or correlates among girls married during different stages of adolescence or have focused on girls married very early (before age 15).

METHODS: Data from a population-based survey conducted in 2009-2010 in seven Ethiopian regions were used to examine early marriage among 1,671 women aged 20-24. Cross-tabulations and logistic regression were used to compare characteristics and contextual factors among girls married before age 15, at ages 15-17 or at ages 18-19 and to identify factors associated with selected marital outcomes.

RESULTS: Seventeen percent of respondents had married before age 15 and 30\% had married at ages 15-17. Most of those who married before age 18 had never been to school. Compared with young women who had married at ages 18-19, those married before age 15 were less likely to have known about the marriage beforehand (odds ratio, 0.2) and more likely to have experienced forced first marital sex (3.8). Educational attainment was positively associated with foreknowledge and wantedness of marriage and with high levels of marital discussions about fertility and reproductive health issues.

CONCLUSIONS: Initiatives addressing the earliest child marriages should focus on girls who have left or never attended school. Given the vulnerability of girls married before age 15, programs should pay special attention to delaying very early marriages.

International Perspectives on Sexual and Reproductive Health, 2013, 39(1):6-13, doi: 10.1363/3900613
Levels of child marriage, defined as marriage before age $18,{ }^{1}$ are generally declining worldwide, although a substantial proportion of females in Sub-Saharan Africa and South Asia are still married before their 18 th birthday. ${ }^{2}$ Estimates suggest that if marriage patterns remain unchanged, during the next 10 years more than 100 million young women will be married during their adolescence (i.e., before age 18), and roughly 14 million will be married by age $15 .^{3}$

Early marriage is associated with elevated total fertility rates. ${ }^{4}$ A review of Demographic and Health Survey data from 51 countries found that $90 \%$ of first births to mothers younger than 18 took place within marriage, ${ }^{5}$ and not to unwed mothers, as is often assumed. In many countries, childbearing is typically expected soon after marriage, and these early first births are riskier than later births. Complications of pregnancy and delivery are the leading causes of death among females aged 15-19, and girls who bear children before age 15 are five times as likely as older mothers to die of pregnancy-related causes. ${ }^{6}$ Some evidence from Sub-Saharan Africa suggests that women who marry early have an increased risk of HIV infection; the infection rate among married adolescents is 50\% higher than that among their unmarried, sexually active peers. ${ }^{7,8}$ The higher rate of infection among married than unmarried adolescents may be related to the former having a greater frequency of intercourse, having lower rates of condom use and having partners who are older and more experienced (and hence more likely to be HIV-positive) than the partners of unmarried adolescents. ${ }^{9}$

In regions where child marriage is still common, cultural beliefs and social norms generally uphold the practice. In addition, these areas are often characterized by high rates of poverty, low levels of development, and limited schooling and work opportunities. ${ }^{2,10}$ Young women who marry early are generally at a distinct disadvantage within the marriage. They usually enter marriage poorly equipped to negotiate adult marital roles, given their limited education, knowledge and skills, ${ }^{11}$ and their marriages are more likely than others to have been arranged. ${ }^{8,12}$ Moreover, the age differences between them and their husbands tend to be larger than those in the relationships of women who marry later, 8,12 and these large imbalances can compromise a woman's power within the marriage; she may have little involvement in decisions related to family planning, childbearing and use of maternal and child health services.

The transition to marriage has a significant impact on the quality of a young woman's life, as it shifts her focus, while she is still young, from education and personal development to family life and motherhood. ${ }^{12}$ However, relatively little is known about the terms and conditions of these early marriages, although studies have examined the relationship between early marriage and fertility out- 
comes. In addition, some evidence suggests that women who marry early are at increased risk of intimate partner violence. $^{13-15}$ A recent study in India found that early marriage is associated with low involvement in the decision to marry, fewer interactions with one's spouse and elevated risk of intimate partner violence. However, researchers found no association between early marriage and decision making or self-efficacy. ${ }^{16}$

\section{Marriage in Ethiopia}

Because an estimated 80 different ethnic groups live in Ethiopia, ${ }^{17}$ marriage practices vary greatly. ${ }^{18}$ Overall, most marriages are arranged by families. ${ }^{18,19}$ Typically, notwithstanding the diversity of customs, elders from the prospective groom's family approach the father of the prospective bride to propose a marriage. If the union is acceptable, the families negotiate marital exchanges and set a wedding date. In most cases, the gifts in marital exchanges are given by the groom's family to the bride's or (among the Amhara people) are given to the new couple by both sides of the family. ${ }^{18,20}$ Though less common, marriage by abduction is also practiced in Ethiopia, mainly in the country's southern regions. In most of these cases, the abductor, with the support of friends and family members, kidnaps a young woman in the course of her normal activities, such as fetching water or collecting firewood. The young woman is then raped by her abductor or gang raped, after which she and her family feel they have no choice but to agree to a marriage because the victim's perceived marriageability is severely compromised. ${ }^{18}$ The highest rates of early marriage are found in the Amhara region, the country's second largest, where the median age at marriage among females aged 20-49 is $14.4 .{ }^{17}$ Orthodox Christianity is the region's (and Ethiopia's) dominant religion; Islam is the country's second most common religion. ${ }^{21}$

\section{Refining Adolescent Age Groupings}

Studies generally define "early marriage" as marriage before age 18 or, alternatively, before age 20. In some settings, however, a considerable proportion of young women marry during early adolescence (before age 15). In Bangladesh, Niger and Chad, more than a third of females are married by their 15 th birthday. ${ }^{22}$ Ethiopia is another country characterized by high levels of very early marriage; according to the 2011 Demographic and Health Survey, 27\% of women aged 20-29 had married by age $15 .^{17}$

Adolescence is a period of rapid physical, psychological and cognitive changes. To explore the question "How young is too young?" for adolescents to undergo adult transitions such as having sex or getting married, DixonMueller reviewed data on physiological and cognitive readiness and on common legal and international standards related to consent. ${ }^{23}$ She recommended that researchers use more refined age groupings in adolescent studies, such as early adolescence (ages 10-11 and 12-14), middle adolescence (ages 15-17) and late adolescence (ages 18-19), and concluded that early adolescence is generally "too early" to start having sex or get married, while late adolescence is probably "old enough." 23

Despite the rapid changes that occur during these years and the extreme physiological and cognitive differences between younger and older adolescents, few studies have examined potential differences in the characteristics and conditions of young women married during early, middle and late adolescence. ${ }^{24}$ This study compares young women married "too early" with those married later, and focuses on two questions. First, what are the background and family characteristics of girls who marry at different stages of adolescence (early, middle and late) and those who do not marry before age 20? Such information will give programmers important direction on how to target prevention programs to the girls most vulnerable to marriage at a very early age. Second, do the terms of marriage and the nature of marital relationships differ according to the age at which girls marry? To address this question, the study explores the extent to which girls married during early, middle or late adolescence were able to choose their partner, had foreknowledge of the marriage and participated in marital and household decisions. Analyses also examine markers of inequitable relationships, such as nonconsensual sexual relations and intimate partner violence. Findings could assist programmers in designing more focused and nuanced programmatic content and support to young women who have already married at a young age.

\section{METHODS}

Data for this study come from a population-based survey conducted in Ethiopia in 2009-2010 among young people aged 12-24. The information in the data set on the context of marriage and marital relations is far more extensive than that currently available in Demographic and Health Surveys. The survey took place in seven of Ethiopia's nine major regions: Addis Ababa; Afar; Amhara; Beneshangul Gumuz; Oromiya; the Southern Nations, Nationalities and Peoples Region (SNNPR); and Tigray. As the study was serving as a baseline survey for planned interventions, 31 districts or "woredas" were chosen from planned intervention and control areas; from these districts, 252 enumeration areas (36 per region) were selected at random.

A census was conducted of all households in each enumeration area selected for the study in order to establish a sampling frame. Once households were listed, potential respondents were selected using a random number function available in SPSS. One respondent aged 12-24 was selected from each household, and 1,440 from each region, yielding a final sample of 10,080 males and females.

The survey questionnaires were largely closed-ended instruments that covered a range of issues, including education, attitudes, self-esteem, puberty, sexual experience, marriage, parenthood, family planning, HIV/AIDS and violence. Questionnaires were translated from English into three local languages (Amharic, Oromiffa and Tigrigna), back-translated and pretested through multiple rounds.

The 262 interviewers who fielded the survey had a min- 
TABLE 1. Selected characteristics of Ethiopian women aged 20-24, by age at first marriage, 2009-2010

\begin{tabular}{|c|c|c|c|c|c|}
\hline Characteristic & $\begin{array}{l}\text { Married } \\
\text { before age } 15 \\
(\mathrm{~N}=275)\end{array}$ & $\begin{array}{l}\text { Married at } \\
\text { ages 15-17 } \\
(\mathrm{N}=500)\end{array}$ & $\begin{array}{l}\text { Married at } \\
\text { ages 18-19 } \\
(\mathrm{N}=432)\end{array}$ & $\begin{array}{l}\text { Did not marry } \\
\text { before age } 20 \\
(\mathrm{~N}=464)\end{array}$ & $\begin{array}{l}\text { All } \\
(\mathrm{N}=1,671)\end{array}$ \\
\hline \multicolumn{6}{|l|}{ PERCENTAGE DISTRIBUTIONS } \\
\hline Urban & 17.8 & 28.4 & 40.7 & 65.1 & 40.3 \\
\hline Rural & 82.2 & 71.6 & 59.3 & 34.9 & 59.7 \\
\hline \multicolumn{6}{|l|}{ Region*** } \\
\hline Tigray & 10.2 & 15.6 & 14.6 & 9.1 & 12.6 \\
\hline Afar & 16.0 & 27.8 & 17.1 & 8.8 & 17.7 \\
\hline Amhara & 37.1 & 8.8 & 6.5 & 7.5 & 12.4 \\
\hline Oromiya & 8.4 & 15.0 & 23.1 & 14.7 & 16.0 \\
\hline Beneshangul-Gumz & 20.0 & 17.8 & 16.0 & 5.8 & 14.3 \\
\hline SNNPR & 6.9 & 10.8 & 13.0 & 20.0 & 13.3 \\
\hline Addis Ababa & 1.5 & 4.2 & 9.7 & 34.1 & 13.6 \\
\hline \multicolumn{6}{|l|}{ Religion*** } \\
\hline Orthodox Christian & 61.3 & 39.0 & 50.0 & 62.0 & 52.1 \\
\hline Muslim & 28.8 & 48.4 & 33.3 & 17.3 & 32.5 \\
\hline Protestant & 8.8 & 9.6 & 14.4 & 19.0 & 13.3 \\
\hline Other & 1.1 & 3.0 & 2.3 & 1.7 & 2.1 \\
\hline \multicolumn{6}{|l|}{ Educational attainment $* * *$} \\
\hline None & 78.5 & 65.9 & 41.3 & 17.3 & 47.9 \\
\hline 1-8yrs. & 18.9 & 28.9 & 40.3 & 33.7 & 31.7 \\
\hline $9-12$ yrs. & 2.5 & 5.2 & 17.9 & 44.5 & 19.1 \\
\hline Attended university & 0.0 & 0.0 & 0.5 & 4.5 & 1.4 \\
\hline \multicolumn{6}{|l|}{ Mother's education**** } \\
\hline None & 97.0 & 93.1 & 90.0 & 75.9 & 88.1 \\
\hline Any & 3.0 & 6.9 & 10.0 & 24.1 & 11.9 \\
\hline \multicolumn{6}{|l|}{ Father's education**** } \\
\hline None & 90.7 & 88.3 & 78.9 & 64.4 & 79.7 \\
\hline Any & 9.3 & 11.7 & 21.1 & 35.6 & 20.3 \\
\hline Total & 100.0 & 100.0 & 100.0 & 100.0 & 100.0 \\
\hline \multicolumn{6}{|l|}{ MEANS } \\
\hline No. of children in natal family & 6.5 & 6.5 & 6.5 & 6.2 & 6.4 \\
\hline No. of daughters in natal family* & 3.7 & 3.6 & 3.6 & 3.4 & 3.6 \\
\hline
\end{tabular}

${ }^{*} p<.05 .{ }^{* *} p<.01 .{ }^{* * *} p<.001$. Notes: Significance testing assessed differences in percentage distributions or means among women married at different ages Percentages may not total 100.0 because of rounding. SNNPR=Southern Nations, Nationalities and Peoples Region.

imum of 10 years of education, were able to speak local languages, were familiar with the study area, and had experience in previous surveys, especially the Ethiopia Demographic and Health Survey. They were trained to conduct each interview in a private place, out of earshot of other household or community members. If the respondent was not at home, the interviewer arranged a follow-up visit. The interviewer visited the household up to three times to locate and interview the selected resident; if the individual declined to participate or could not be located, no replacement was made. Prior to the interview, informed consent was obtained from each respondent (or, if he or she was younger than 18, from a parent or guardian). If the respondent was a married underage girl, she was considered an emancipated minor and provided informed consent herself; however, permission was also obtained from a senior adult in the household, usually a parent-in-law, in respect of locally appropriate conventions for contacting household members. The study received ethical approval from a local board in Ethiopia and from the institutional review board of the sponsor agency.

\section{Measures and Analysis}

Analyses for this study were restricted to women aged 20-24 so that no respondent was still at risk for marriage during adolescence. Participants were asked if they had ever been married and, if so, the age at which they had first married. Responses were coded according to whether the woman had married before age 15, at ages 15-17, at ages 18-19 or at none of these ages (i.e., not before age 20). The last group included both unmarried women and those who had married after age 19. In all, 1,679 women aged 20-24 were interviewed; eight were excluded from analyses because of incomplete information on marital status or age at marriage, resulting in an analytic sample of 1,671 women.

Ever-married respondents were asked a series of followup questions about the characteristics of the first marriage, including whether it had been arranged or had been chosen by the bride and groom; the primary individual(s) who had decided on and supported the marriage (if it had been arranged); whether the respondent had known about the marriage beforehand; whether she had wanted to marry at that time; whether she had been made to leave 
school to marry; and the length of time she had known the groom before the wedding. Because some investigators have speculated that marriage may be hastened for orphaned girls, we constructed a variable to indicate whether a respondent's mother, father or both had been dead at the time of her marriage.

The survey also explored the nature of husband-wife relations. In one series of questions, young women were asked whether they and their spouse had ever discussed the following four topics: the number of children to have, HIV/AIDS, marital fidelity and use of maternal and child health services. If a respondent reported having discussed all four topics with her spouse, she was coded as having a high level of marital discussion. To assess household decision making, respondents were asked whether they agreed with the statement "You participate in major decisions in the household, such as the decision to sell major assets." Several questions asked about the circumstances related to the first time the respondent had had sex with her spouse, including whether she had started menstruating and whether she had wanted to have sex at the time. Intimate partner violence was assessed by asking the respondent whether the consummation of her marriage had been forced or consensual; whether her husband had ever been physically violent with her (i.e., had pushed, slapped, punched, beaten or kicked her); and whether her husband had hit or beaten her in the past three months.

For each of these measures, we compared respondents married at different stages of adolescence. Differences between subgroups were assessed by chi-square tests (for categorical variables) and tests (for continuous variables). Sample sizes varied slightly among the analyses because of missing data for some variables. Multinomial logistic regression was used to model the odds of having been married at different ages (before age 15, at ages 15-17, at ages 18-19); not having married before age 20 was the reference group. This analysis controlled for residence (urban or rural), region (Amhara or other), ${ }^{*}$ religion (Orthodox Christian, Muslim or other), education (any or none), parental education (any or none), and the number of daughters in the natal home.

The remaining analyses were restricted to respondents who had married before age 20 and examined the relationship between the timing of marriage and aspects of marital relations. Logistic regression was used to model the odds of having known about the marriage in advance, having wanted the marriage, having high levels of discussion with one's husband, having wanted first sex with one's husband and having been subjected to intimate partner violence in the past three months. In addition to including a variable for age at first marriage (before 15 , at ages $15-17$ or at ages 18-19), all of these models controlled for educational attainment (as a continuous variable, in years), residence, region and religion. Because a girl who is in school may be less likely than one who is not to want to be married or to be told about the marriage beforehand, the models on foreknowledge and wantedness of marriage also in-
TABLE 2. Selected measures related to context of marriage, orphanhood and relationship characteristics among married Ethiopian women aged 20-24, by age at first marriage

\begin{tabular}{|c|c|c|c|}
\hline Measure & $\begin{array}{l}\text { Married } \\
\text { before age } 15 \\
(\mathrm{~N}=273)\end{array}$ & $\begin{array}{l}\text { Married at } \\
\text { ages 15-17 } \\
(\mathrm{N}=498)\end{array}$ & $\begin{array}{l}\text { Married at } \\
\text { ages 18-19 } \\
(\mathrm{N}=432)\end{array}$ \\
\hline \multicolumn{4}{|l|}{ CONTEXT OF MARRIAGE } \\
\hline \multicolumn{4}{|l|}{ Marriage arrangement ${ }^{* * *}$} \\
\hline Arranged & 89.0 & 71.1 & 52.1 \\
\hline Chosen & 7.3 & 26.1 & 46.3 \\
\hline Abducted & 3.7 & 2.8 & 1.6 \\
\hline \multicolumn{4}{|l|}{ Main supporters of marriage $\neq$} \\
\hline Father*** & 73.7 & 64.3 & 56.3 \\
\hline Mother*** & 81.0 & 68.7 & 64.0 \\
\hline Aunt* & 14.2 & 12.0 & 7.9 \\
\hline Uncle** & 17.5 & 11.8 & 9.1 \\
\hline Sister ${ }^{* *}$ & 6.6 & 7.3 & 12.9 \\
\hline Brother & 10.9 & 8.9 & 11.7 \\
\hline Grandmother*** & 8.9 & 4.8 & 2.1 \\
\hline Grandfather** & 4.7 & 2.6 & 0.7 \\
\hline Religious leader & 0.4 & 1.4 & 1.4 \\
\hline Community leader & 0.4 & 0.6 & 0.2 \\
\hline Knew about marriage beforehand $* * *$ & 32.7 & 65.6 & 83.0 \\
\hline Wanted to get married at the time ${ }^{* * *}$ & 30.7 & 64.0 & 79.7 \\
\hline Made to leave school to marry & 5.8 & 9.4 & 10.6 \\
\hline \multicolumn{4}{|l|}{ ORPHANHOOD } \\
\hline Father alive at time of wedding & 83.6 & 81.3 & 80.7 \\
\hline Mother alive at time of wedding & 90.1 & 87.5 & 88.6 \\
\hline Neither parent alive at time of wedding & 2.9 & 4.8 & 4.9 \\
\hline \multicolumn{4}{|l|}{ RELATIONSHIP CHARACTERISTICS } \\
\hline \multicolumn{4}{|l|}{$\begin{array}{l}\text { Length of time knew husband } \\
\text { before wedding }\end{array}$} \\
\hline Met on wedding day & 70.9 & 43.3 & 21.1 \\
\hline$<1$ month & 5.5 & 10.2 & 10.0 \\
\hline $1-12$ months & 5.1 & 15.4 & 20.4 \\
\hline$>1 \mathrm{yr}$ & 7.6 & 11.6 & 32.5 \\
\hline Since childhood & 10.9 & 19.4 & 16.0 \\
\hline \multicolumn{4}{|l|}{ Age difference ${ }^{* * *}$} \\
\hline$>10$ yrs.younger & 21.9 & 16.4 & 12.8 \\
\hline $6-10$ yrs.younger & 47.8 & 38.3 & 35.6 \\
\hline $1-5$ yrs.younger & 28.5 & 44.5 & 48.4 \\
\hline Same age or older & 1.8 & 0.8 & 3.2 \\
\hline Mean age difference with husband (yrs.) ${ }^{* * *}$ & -8.0 & -7.3 & -6.4 \\
\hline
\end{tabular}

${ }^{*} \mathrm{p}<.05 .{ }^{* *} \mathrm{p}<.01 .{ }^{* * *} \mathrm{p}<.001$. $¥$ Among women with arranged marriages; multiple responses possible. Notes: Significance testing assessed differences in percentage distributions, percentages or means among groups of women married at different ages. Unless otherwise noted, all values are percentages.

cluded a variable for whether the girl had been forced to leave school to marry. The models for marital discussion, forced first sex and intimate partner violence controlled for age difference with one's spouse, because large differences may be associated with power differentials in relationships.

\section{RESULTS}

\section{Sample Characteristics and Early Marriage}

Of the 1,671 women in the sample, $60 \%$ resided in rural areas and $40 \%$ in urban areas (Table 1). Levels of education were low: Forty-eight percent of respondents had nev-

\footnotetext{
*The Amhara region was singled out because early marriage is more common there than elsewhere in Ethiopia.
} 
er been to school, and 32\% had completed just $1-8$ years of schooling. Only one in five young women had attained some secondary education. Seventeen percent of respondents had married before age 15, while 30\% had married at ages $15-17$ and $26 \%$ at ages 18 or 19 (not shown). The remaining $27 \%$ had not married during adolescence. Ten percent of women who had married before age 20, and $7 \%$ of the full sample, were already divorced.

Among women married before age 15, 82\% resided in rural areas and 79\% had never been to school (Table 1). Only 3\% had attained any secondary schooling. Women who had married very early were especially likely to live in the Amhara region: Thirty-seven percent of women married before age 15 lived there, compared with 7-9\% of those who had married later or not at all. The younger a woman had been at the time of her marriage, the more likely it was that her parents had no education. Among respondents married before age 15, 97\% had mothers with no education and $91 \%$ had fathers with no education; among those who had not married during adolescence, $76 \%$ and $64 \%$, respectively, had mothers and fathers with no education.

\section{Terms of Marriage and Decision Making}

The majority of women who were married before age 20 had had arranged marriages, and age at marriage was inversely related to the likelihood that the marriage had been arranged (Table 2, page 9). Nine-tenths of young women married before age 15 had married by arrangement, compared with half of those married at ages 18-19.

Mothers and fathers were the main decision makers in arranging these marriages, and the younger the bride, the more pronounced their influence was. Among women married before age 15 , some $81 \%$ said that their mother had been a primary arranger or supporter of the marriage,

TABLE 3. Selected measures related to marital discussions, decision making, first sex with spouse and intimate partner violence among married Ethiopian women aged 20-24, by age at first marriage

Measure
Married Married at Married at before age 15 ages 15-17 ages 18-19 $(\mathrm{N}=273) \quad(\mathrm{N}=498) \quad(\mathrm{N}=432)$

\section{Marital discussions/decision making}

Discussed no. of children to have

Discussed HIV/AIDS***

Discussed being faithful in marriage $\mathrm{e}^{* * *}$

Discussed MCH services***

Discussed all four topics above ${ }^{* *}$

Participates in major household decisions

\section{First sex with spouse}

Was woman's sexual initiation Occurred before wedding ${ }^{* * *}$ Respondent had started menstruating ${ }^{* * *}$

Was wanted ${ }^{* * *}$

\section{Intimate partner violence}

First sex with husband was forced ${ }^{* * *}$

Husband has ever been physically violent with respondent

Husband hit or beat spouse in past three months**

$\begin{array}{lll}41.4 & 41.0 & 47.3 \\ 37.2 & 41.2 & 56.0 \\ 44.3 & 43.1 & 55.9 \\ 34.4 & 37.2 & 49.0 \\ 14.5 & 17.8 & 23.8 \\ 69.7 & 62.9 & 63.9\end{array}$

\section{6}

1.5

38.6

49.1$$
96.8
$$$$
3.8
$$$$
79.3
$$$$
74.3
$$

13.7

93.7

85.3

${ }^{*} \mathrm{p}<.05 .{ }^{* *} \mathrm{p}<.01 .{ }^{* * * *} \mathrm{p}<.001$. Notes: Significance testing assessed differences among groups of women married at different ages. All values are percentages. $\mathrm{MCH}=$ maternal and child health. and $74 \%$ reported that their father had been one. Younger brides were less likely than older ones to have been forewarned about the marriage and to have wanted it. Of those married before age 15, only 33\% had known about the marriage beforehand and just $31 \%$ had wanted to be married at the time. The proportion of women who reported having left school to get married was small, which may be due in part to the low proportion of respondents who had ever attended school at all. Among the youngest brides, only $6 \%$ had withdrawn from school to marry, while $9 \%$ of women married at ages 15-17 reported having left school to get married. Orphanhood was not associated with early marriage, a finding consistent with previous studies. ${ }^{25}$

A substantial majority of the youngest brides (71\%) had not met their spouse until the wedding day; the proportions were smaller among those married at ages 15-17 (43\%) or ages $18-19$ (21\%). As in earlier studies, ${ }^{12}$ the younger the bride, the greater the age difference between her and her spouse. On average, young women who married during early adolescence were eight years younger than their spouse.

\section{Relationships with Husbands}

Older age at marriage was positively associated with the likelihood that a young woman had discussed HIV/AIDS, marital fidelity and use of maternal and child health services with her husband, although no association was apparent for discussions of fertility intentions (Table 3). Respondents married at ages 18-19 were more likely than those married before age 15 to have discussed all four topics (24\% vs. $15 \%$; p $<0.01)$.

The vast majority of respondents married during adolescence (95-97\%) reported that their first sexual relations had been with their spouse. However, those who had married before age 15 were less likely to have wanted to experience sexual initiation than were those who had married at ages $18-19$ (49\% vs. $85 \%$; $<<0.001$ ), and only $39 \%$ of the youngest brides had started menstruating by the time the marriage was consummated. Likewise, the youngest brides had experienced high levels of forced first sex with their husbands (32\%) and were more likely than older brides to have recently experienced intimate partner violence at the hands of their husbands ( $7 \%$ vs. $2-3 \%$; $p<0.001$ ).

\section{Multivariate Analyses}

Residing in a rural area and having not attended school were each associated with elevated odds of marrying before age 20, although the magnitude of these associations decreased with later age at marriage (Table 4). The odds that a respondent had married before age 15 were elevated fourfold if she lived in a rural rather than an urban area (odds ratio, 4.2); rural residence was associated with a nearly threefold elevation in the odds of marriage at ages 15-17 (2.8) and a twofold elevation in the odds of marriage at ages 18-19 (2.1). Likewise, compared with women who had some degree of formal education, unschooled women had nine times the odds of having married before 
age 15 (9.2) and five times the odds of having married at ages 15-17 (5.1) than of not having married during adolescence. Residing in the Amhara region was associated with elevated odds of marriage before age 15 (5.7), but not of marriage during middle or late adolescence.

Education level and age at marriage were both positively associated with having known about one's marriage beforehand and having wanted to get married at the time (Table 5). Young women who had married at ages 15-17 had roughly half the odds of those who had married at ages 18-19 to have had forewarning of the marriage or to have wanted the marriage (odds ratios, 0.5 and 0.6, respectively); those who had married before age 15 had one-fifth the odds of 18-19-year-old brides of having known about or wanted the marriage ( 0.2 for each). Respondents who had been made to leave school in order to marry were less likely than those who had not been forced to leave school (including those who had never attended school in the first place) to have wanted to marry at the time (odds ratio 0.5 ).

A high level of discussion with one's spouse was positively associated with educational attainment, and negatively associated with living in a rural region, with residence in Amhara and with being Muslim (Table 6). Age at marriage was not associated with level of marital discussion.

However, early marriage was associated with having experienced forced first sex with one's husband, and marginally associated with having been hit or beaten in the last three months. The odds that a woman who had married before age 15 had experienced forced first sex with her spouse were nearly four times those of respondents who had married at ages 18-19 (odds ratio, 3.8). Young women who had married at ages 15-17 had nearly twice the odds of having experienced forced first sex as did those who had married later in adolescence (1.9).

\section{LIMITATIONS}

The study has several limitations. Respondents, particularly those with relatively little education, may have misreported their age, their age at marriage or their husband's age. We were unable to control for poverty in the bivariate and multivariate models because the survey elicited information on assets and amenities in the respondent's current household, rather than in their natal household; the latter would have been a more appropriate measure of whether poverty is a driver of early marriage. Finally, some degree of underreporting of intimate partner violence likely occurred, given the sensitivities around the topic and the stigma associated with reporting negative experiences with one's husband. Smaller scale, subregional studies in Ethiopia have recorded substantially higher rates of intimate partner violence than this one did. ${ }^{26}$

\section{DISCUSSION}

In this study, one in six young women in Ethiopia had married by age 15 . Those married at very early ages were less likely than others to have known about the marriage in advance or to have wanted it, and they were at elevated
TABLE 4. Adjusted odds ratios (and 95\% confidence intervals) from multinomial logistic regression analyses examining factors associated with age at marriage among Ethiopian women aged 20-24 who married before age 20

\begin{tabular}{|c|c|c|c|}
\hline Characteristic & $\begin{array}{l}\text { Married before } \\
\text { age } 15\end{array}$ & $\begin{array}{l}\text { Married at } \\
\text { ages 15-17 }\end{array}$ & $\begin{array}{l}\text { Married at } \\
\text { ages 18-19 }\end{array}$ \\
\hline \multicolumn{4}{|l|}{ Resides in rural area } \\
\hline Yes & $4.18(2.70-6.48)^{* * *}$ & $2.77(1.98-3.87)^{* * *}$ & $2.13(1.55-2.92)^{* * *}$ \\
\hline No (ref) & 1.00 & 1.00 & 1.00 \\
\hline \multicolumn{4}{|l|}{ Resides in Amhara region } \\
\hline Yes & $5.70(3.32-9.79)^{* * *}$ & $1.42(0.82-2.45)$ & $0.84(0.48-1.47)$ \\
\hline No (ref) & 1.00 & 1.00 & 1.00 \\
\hline \multicolumn{4}{|l|}{ Religion } \\
\hline Orthodox Christian & $1.01(0.57-1.81)$ & $0.87(0.56-1.35)$ & $1.09(0.73-1.62)$ \\
\hline Muslim & $1.76(0.94-3.29) \dagger$ & $3.12(1.92-5.05)^{* * *}$ & $2.11(1.32-3.36)^{* *}$ \\
\hline Other (ref) & 1.00 & 1.00 & 1.00 \\
\hline \multicolumn{4}{|l|}{ Ever attended school } \\
\hline Yes (ref) & 1.00 & 1.00 & 1.00 \\
\hline No & $9.24(5.94-14.36)^{* * * *}$ & $5.11(3.58-7.29)^{* * *}$ & $2.25(1.58-3.20)^{* * *}$ \\
\hline \multicolumn{4}{|l|}{ Mother ever attended school } \\
\hline Yes (ref) & 1.00 & 1.00 & 1.00 \\
\hline No & $2.53(1.05-6.12)^{*}$ & $1.30(0.74-2.29)$ & $1.68(1.02-2.75)^{*}$ \\
\hline \multicolumn{4}{|l|}{ Father ever attended school } \\
\hline Yes (ref) & 1.00 & 1.00 & 1.00 \\
\hline No & $0.87(0.47-1.59)$ & $1.13(0.71-1.81)$ & $0.91(0.61-1.37)$ \\
\hline No. of daughters in natal family & $1.14(1.02-1.27)^{*}$ & $1.10(1.00-1.20)^{*}$ & $1.06(0.97-1.16)$ \\
\hline
\end{tabular}

${ }^{*} \mathrm{p}<.05 .{ }^{* *} \mathrm{p}<.01 .{ }^{* * *} \mathrm{p}<.001 .+\mathrm{p}<.10$. Notes: Reference group is women who did not marry before age 20. Analysis excludes 165 women for whom information on one or more independent variables was missing, yielding a sample of 1,506 women.

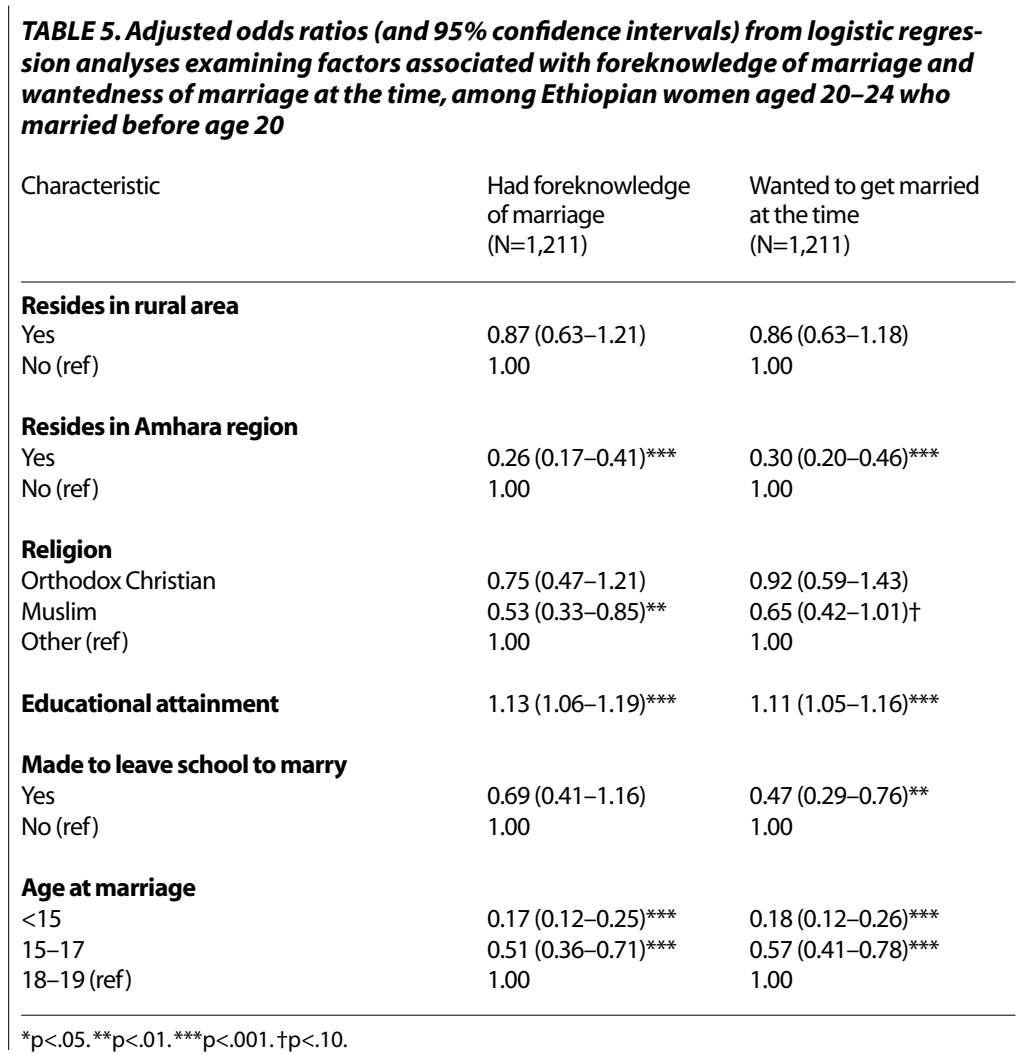




\begin{tabular}{|c|c|c|c|}
\hline Characteristic & $\begin{array}{l}\text { High level of } \\
\text { marital } \\
\text { discussion } \\
(\mathrm{N}=1,196)\end{array}$ & $\begin{array}{l}\text { First sex with } \\
\text { husband } \\
\text { was forced } \\
(\mathrm{N}=1,181)\end{array}$ & $\begin{array}{l}\text { Husband was } \\
\text { violent with } \\
\text { respondent in } \\
\text { past three months } \\
(\mathrm{N}=1,157)\end{array}$ \\
\hline \multicolumn{4}{|l|}{ Resides in rural area } \\
\hline Yes & $0.63(0.45-0.89)^{* *}$ & $1.13(0.76-1.68)$ & $0.64(0.31-1.33)$ \\
\hline No (ref) & 1.00 & 1.00 & 1.00 \\
\hline \multicolumn{4}{|l|}{ Resides in Amhara region } \\
\hline Yes & $0.46(0.26-0.80)^{* *}$ & $1.99(1.26-3.15)^{* *}$ & $1.48(0.60-3.67)$ \\
\hline No (ref) & 1.00 & 1.00 & 1.00 \\
\hline \multicolumn{4}{|l|}{ Religion } \\
\hline Orthodox Christian & $0.96(0.63-1.46)$ & $0.95(0.54-1.65)$ & $0.29(0.12-0.69)^{* *}$ \\
\hline Muslim & $0.40(0.25-0.65)^{* * *}$ & $1.19(0.69-2.06)$ & $0.29(0.10-0.61)^{* *}$ \\
\hline Other (ref) & 1.00 & 1.0 .0 & 1.00 \\
\hline Educational attainment & $1.15(1.10-1.21)^{* * * *}$ & $0.97(0.91-1.03)$ & $0.92(0.82-1.03)$ \\
\hline Age difference with spouse & $1.01(0.97-1.04)$ & $1.01(0.97-1.04)$ & $1.01(0.94-1.09)$ \\
\hline \multicolumn{4}{|l|}{ Age at marriage } \\
\hline$<15$ & $1.16(0.81-1.65)$ & $3.80(2.35-6.15)^{* * *}$ & $2.14(0.93-4.93) \dagger$ \\
\hline $15-17$ & $1.16(0.73-1.85)$ & $1.91(1.23-2.95)^{* *}$ & $0.71(0.30-1.66)$ \\
\hline 18-19(ref) & 1.00 & 1.00 & 1.00 \\
\hline
\end{tabular}

risk of intimate partner violence, including forced first marital sex. The majority of young women who had married before age 15 had experienced first marital sex before they started menstruating. These results are consistent with those of other studies that reported intimate partner violence in the context of early marriages. ${ }^{27}$

Young women who had married early tended to live in rural areas, especially in Amhara. This underscores the need for geographic targeting of initiatives addressing early marriage. However, such programs rarely make distinctions between girls married at different stages of adolescence. Those married during early adolescence are arguably the most vulnerable, as they frequently enter marital relations without foreknowledge, through force and at a stage in their life that is considered too early from multiple perspectives. Findings from this study suggest that investments in programs addressing early marriage should be concentrated in areas where considerable proportions of girls are married before age 15 .

Most young women who had married at a very early age had never been to school. Contrary to common assumptions that school dropout precedes early marriage, only a small minority of respondents had been made to withdraw from school to get married. That most Ethiopian girls married at a very early age had never been to school reflects a lack of opportunities for, and investment in, these girls, rather than issues related to the quality or protectiveness of the schooling environment. This has implications for the design of programs aimed at reducing the prevalence of child marriage. Girls who are young and out of school may be highly vulnerable to being married off; if so, community-based programs that get girls into school and keep them there may be more effective at combating early child marriage than are strategies to address the school environment or community attitudes toward early marriage. Programs that implement strategies within the school, such as girls' advisory committees or school committees to which girls can report an impending marriage, may miss the majority of those who are most vulnerable to early marriage-unschooled girls who reside in rural regions where large proportions of girls marry by age 15 . Interventions such as Berhane Hewan in Ethiopia have been successful in increasing school attendance and preventing marriage among girls aged $10-14$ by providing school materials and conditional cash transfers. ${ }^{28}$ Such initiatives demonstrate that families are amenable to delaying these earliest of child marriages, and that direct programmatic investments in the most vulnerable girls can be highly effective

\section{REFERENCES}

1. United Nations Children's Fund (UNICEF), Early Marriage: Child Spouses, Florence, Italy: UNICEF, 2001

2. Lloyd C, ed., Growing Up Global: Changing Transitions to Adulthood in Developing Countries, Washington, DC: National Academies Press, 2005

3. BruceJ, Child marriage in the context of the HIV epidemic, Transitions to Adulthood Brief, New York: Population Council, 2005, No. 11.

4. Raj A et al., Prevalence of child marriage and its effect on fertility and fertility-control outcomes of young women in India: a cross-sectional, observational study, Lancet, 2009, 373(9678):1883-1889.

5. Haberland $\mathrm{N}$ et al., Early marriage and adolescent girls, YouthLens, Arlington, VA, USA: YouthNet, 2005, No. 15.

6. Murphy E and Carr D, Powerful partners: adolescent girls' education and delayed childbearing, Policy Brief, Washington, DC: Population Reference Bureau, 2007.

7. Clark S, Early marriage and HIV risks in Sub-Saharan Africa, Studies in Family Planning, 2004, 35(3):149-160.

8. Glynn JR et al., Why do young women have a much higher prevalence of HIV than young men? A study in Kisumu, Kenya and Ndola, Zambia, AIDS, 2001, 15(Suppl. 4):S51-S60

9. Clark S, Bruce J and Dude A, Protecting young women from HIV/ AIDS: the case against child and adolescent marriage, International Family Planning Perspectives, 2006, 32(2):79-88.

10. United Nations Population Fund (UNFPA), State of the World Population 2005: The Promise of Equality, New York: UNFPA, 2005.

11. UNICEF, State of the World's Children 2011: Adolescence, An Age of Opportunity, New York: UNICEF, 2011.

12. Mensch B, Bruce J and Greene M, The Uncharted Passage: Girls' Adolescence in the Developing World, New York: Population Council, 1998.

13. United States Agency for International Development (USAID), Early marriage and youth reproductive health, Fact Sheet on Youth Reproductive Health Policy, Washington, DC: USAID, 2009.

14. Hindin MJ, Kishor S and Ansara DL, Intimate Partner Violence Among Couples in 10 DHS Countries: Predictors and Health Outcomes, Calverton, MD, USA: Macro International, 2008.

15. Speizer IS and Pearson E, Association between early marriage and intimate partner violence in India: a focus on youth from Bihar and Rajasthan, Journal of Interpersonal Violence, 2011, 26(10):1963-1981.

16. Santhya KG et al., Associations between early marriage and young women's marital and reproductive health outcomes: evidence from India, International Perspectives on Sexual and Reproductive Health, 2010, 36(3):132-139. 
17. Central Statistical Agency of Ethiopia and ICF International, Ethiopia Demographic and Health Survey 2011, Addis Ababa, Ethiopia: Central Statistical Agency; and Calverton, MD, USA: ICF International, 2012.

18. Ye Ethiopia Goji Limadawi Dirgitoch Aswogaj Mahiber (EGLDAM), Old Beyond Imaginings: Ethiopia Harmful Traditional Practices, second ed., Addis Ababa: EGLDAM, 2008.

19. Tilson D and Larsen U, Divorce in Ethiopia: the impact of early marriage and childlessness, Journal of Biosocial Science, 2000, 32(3):355-372.

20. Boyden J, Pankhurst A and Tafere Y, Child protection and harmful traditional practices: female early marriage and genital modification in Ethiopia, Development in Practice, 2012, 22(4):510-522.

21. Federal Democratic Republic of Ethiopia Population Census Commission, Summary and Statistical Report of the 2007 Population and Housing Census, Addis Ababa, Ethiopia: Population Census Commission, 2008.

22. World Vision, Before She's Ready: 15 Places Girls Marry by 15, Federal Way, WA, USA: World Vision, 2008.

23. Dixon-Mueller R, How young is "too young"? Comparative perspectives on adolescent sexual, marital, and reproductive transitions, Studies in Family Planning, 2008, 39(4):247-262.

24. Hervish A and Feldman-Jacobs C, Who speaks for me? Ending child marriage, Policy Brief, Washington, DC: Population Reference Bureau, 2011.

25. Palermo T and Peterman A, Are female orphans at risk for early marriage, early sexual debut, and teen pregnancy? Evidence from SubSaharan Africa, Studies in Family Planning, 2009, 40(2):101-112.

26. World Health Organization (WHO), WHO Multi-Country Study on Women's Health and Domestic Violence Against Women: Summary Report of Initial Results on Prevalence, Health Outcomes and Women's Responses, Geneva: WHO, 2005

27. Santhya KG et al., Consent and coercion: examining unwanted sex among married young women in India, International Family Planning Perspectives, 2007, 33(3):124-132.

28. Erulkar AS and Muthengi E, Evaluation of Berhane Hewan: a program to delay child marriage in rural Ethiopia, International Perspectives on Sexual and Reproductive Health, 2009, 35(1):6-14.

\section{RESUMEN}

Contexto: A nivel mundial, una proporción considerable de mujeres contrae matrimonio durante la niñez. Existen muchos estudios sobre el matrimonio temprano (antes de los 18 años de edad), pero hay pocos que comparen los resultados y las correlaciones entre niñas casadas en diferentes etapas de la adolescencia, o que se centren en las niñas casadas a edad muy temprana (antes de los 15 años).

Métodos: Se utilizaron datos de un estudio poblacional conducido en siete regiones de Etiopía entre 2009 y 2010, con el fin de examinar el matrimonio temprano en 1.671 mujeres jóvenes con edades entre los 20 y los 24 años. Se usaron tabulaciones cruzadas y modelos de regresión logística para comparar características y factores contextuales entre las niñas casadas antes de los 15, entre los 15 y los 17, y entre los 18 y los 19 años, así como para identificar factores asociados con situaciones maritales específicas.

Resultados: Un 17\% de las entrevistadas contrajo matrimonio antes de los 15 años, y un 30\% entre los 15 y los 17 años de edad. La mayoría de las que se casaron antes de los 18 años nunca había ido a la escuela. En comparación con las mujeres que contrajeron matrimonio entre los 18 y los 19 años, las jóve- nes que se casaron antes de los 15 años mostraron una probabilidad menor de saber con anterioridad sobre su matrimonio (cociente de probabilidades, 0,2) y una mayor probabilidad de que sus primeras relaciones sexuales maritales fueran forzadas $(3,8)$. El nivel educativo mostró una asociación positiva con el conocimiento previo y con el deseo de contraer matrimonio, así como con altos niveles de diálogo marital sobre temas de fecundidad y salud reproductiva.

Conclusiones: Las iniciativas para abordar los matrimonios infantiles a edades muy tempranas deberían centrarse en las niñas que han abandonado o que nunca asistieron a la escuela. Dada la vulnerabilidad de las niñas que se casan antes de los 15 años, los programas deberían centrarse especialmente en retrasar los matrimonios muy tempranos.

\section{RÉSUMÉ}

Contexte: Partout dans le monde, les femmes sont mariées, en proportion considérable, durant l'enfance. Si de nombreuses études se sont penchées sur le mariage précoce (avant l'âge de 18 ans), peu ont comparé les résultats ou les corrélats parmi les filles mariées aux différentes phases de l'adolescence ou se sont concentrées sur les filles mariées à un très jeune âge (avant 15 ans).

Méthodes: Les données d'une étude en population générale menée en 2009-2010 dans sept régions d'Éthiopie ont servi à l'examen du mariage précoce parmi 1.671 jeunes femmes âgées de 20 à 24 ans. L'analyse procède par tableaux croisés et régression logistique pour comparer les caractéristiques et les facteurs contextuels parmi les filles mariées, avant 15 ans, aux âges de 15 à 17 ans et à 18 ou 19 ans, ainsi que pour identifier les facteurs associés aux résultats conjugaux sélectionnés.

Resultats: Dix-sept pour cent des répondantes avaient été mariées avant l'âge de 15 ans, et 30\% entre 15 et 17 ans. La plupart de celles mariées avant l'âge de 18 ans n'avaient jamais été scolarisées. Par rapport aux jeunes femmes mariées aux âges de 18 et 19 ans, celles mariées avant 15 ans étaient moins susceptibles d'avoir été informées du mariage avant le fait $(O R, 0,2)$ et plus susceptibles d'avoir vécu des premiers rapports sexuels conjugaux forcés $(3,8)$. Le niveau d'études s'est révélé associé positivement avec la connaissance préalable et le désir du mariage, ainsi qu'avec de hauts niveaux de discussions conjugales concernant la fécondité et la santé reproductive.

Conclusions: Les initiatives de lutte contre les mariages les plus précoces doivent se concentrer sur les filles qui ne sont plus scolarisées ou qui ne l'ont jamais été. Étant donné la vulnérabilité des filles mariées avant l'âge de 15 ans, les programmes doivent s'efforcer tout particulièrement de différer les mariages fort précoces.

\section{Acknowledgments}

This study was supported by UNFPA Ethiopia. The author thanks Judith Bruce and Sarah Engebretson for helpful comments on earlier drafts of the article.

Author contact: aerulkar@popcouncil.org 